SYLWIA MARCZYK

Wydział Prawa Kanonicznego

Uniwersytetu Kardynała Stefana Wyszyńskiego w Warszawie

\title{
UPRAWNIENIA FAKULTATYWNE SEDZIEGO W PROCEDURZE WYMIARU KAR KOŚCIELNYCH
}

Treść: Wstęp. - 1. Sędziowskie prawo łaski. - 2. Nadzwyczajne złagodzenie kary. - 3. Odłożenie wymiaru kary. - 4. Zaniechanie wymiaru kary. - 5 . Warunkowe zawieszenie wykonania kary. -6 . Nadzwyczajne podwyższenie kary. - 7. Wymiar kar w przypadku zbiegu przestępstw. - Zakończenie.

\section{Wstęp}

Zasadniczo zagadnienie dyskrecjonalnej władzy sędziego ściśle związane jest $\mathrm{z}$ teorią prawa oraz $\mathrm{z}$ posługiwaniem się nim $\mathrm{w}$ praktyce, aczkolwiek relacja ta nie jest zupełnie oczywista. Teoria prawa bowiem skupia się na normach prawnych, na ramach, w jakich prawo ma i powinno oddziaływać, odnosi się do szeroko pojętych reguł, gdyż norma prawna stanowi, nakazuje konkretny model zachowania. $\mathrm{Z}$ drugiej zaś strony mamy do czynienia ze stwierdzeniami zawartymi w owych normach, które wskazują na możność sędziego w dokonaniu konkretnej czynności, w szczególności zastosowania dyspozycji normy prawnej. Bez wątpienia stwierdzić należy, iż stanowczość prawa wyrażona poprzez skonkretyzowane normy prawne, nakazujące określony model postępowania kompatybilna jest $\mathrm{z}$ uprawnieniami przyznanymi sędziemu, który może postąpić w określony sposób, aczkolwiek zgodny z literą prawa. Istotne jest to, iż uprawnienia przyznane sędziemu nie polegają na tym, iż prawo zezwala na ingerowanie $\mathrm{w}$ treść przepisów, bowiem nie można sędziemu prawa ani zmieniać ani tym bardziej tworzyć. Sędzia pozostaje bowiem 
niejako „ustami ustawy”, a więc poprzez znajomość przepisów prawa roztropnie powinien $\mathrm{w}$ sytuacjach, w których prawo zezwala - dokonywać wykładni przepisów na potrzeby konkretnego przypadku ${ }^{1}$. Zdaje się być jednak bardziej odpowiednim pojmowanie zagadnienia dyskrecjonalnej władzy sędziego poprzez pryzmat ujęcia szerokiego zgodnie z którym, dyskrecjonalność władzy sędziego to coś znacznie ważniejszego niż samo uprawnienie nadane sędziemu przez ustawę. Sędzia bowiem posiada niezwykle ważny wkład w cały system stosowania prawa, wywodzenia zasad $\mathrm{z}$ norm prawnych, stosowania klauzul generalnych oraz dokonywania interpretacji prawa zgodnie z zasadami poprzez doprecyzowanie zwrotów niedookreślonych. Tym samym przymiot dyskrecjonalności władzy wymaga od sędziego bardzo dużego zaangażowania, w szczególności w sprawach, w których mamy do czynienia ze skomplikowanym zarówno stanem faktycznym jak i prawnym, kiedy to niejednokrotnie przepisy prawa zdają się być nie do końca jasne, pozostawiające wątpliwości.

Ustawodawca w Kodeksie Prawa Kanonicznego z 1983 r. w kilku przypadkach daje wyraz dyskrecjonalnej władzy sędziego. Uznać należy, że władza ta jest sferą działania, w której organ może działać, rozstrzygać według swojego przekonania - w granicach tzw. swobodnego uznania.

W większości przypadków swoboda przy wymierzaniu kar jest uregulowana ustawowo, aczkolwiek prawodawca daje też margines władzy sędziego i pozostawia mu całkowitą swobodę przy wymierzaniu, zaostrzeniu jak i zaniechaniu nakładania sankcji karnych ${ }^{2}$. W każdym z tych przypadków sędzia musi podejmować decyzje zgodnie ze swoim sumieniem i roztropnością, jak również brać pod uwagę zasadę słuszności oraz okoliczności zewnętrzne ${ }^{3}$. Ustawodawca

\footnotetext{
${ }^{1}$ T. Rakoczy, Słowo wstępne, w: Dyskrecjonalna władza sędziego. Zagadnienia teorii i praktyki, red. M. Dębiński, R. Pelewicz, T. Rakoczy, Tarnobrzeg 2012, s. 9-11.

${ }^{2}$ J. Syry jczy K, Sankcje w Kościele. Część ogólna. Komentarz. Warszawa 2008, s. 264.

${ }^{3}$ T. Pawluk, Prawo kanoniczne według Kodeksu Jana Pawła II, T. III-IV, 1984-1990, Olsztyn, s. 103.
} 
kodeksowy poprzez nadanie tak dużej autonomii w działaniu osobie sędziego ukazuje jego istotną rolę i sytuuje go bardzo wysoko w hierarchii podmiotów władzy.

Sędzia wykonuje władzę społeczną, gdyż to ona daje możliwość wydawania decyzji, które wiążą inne podmioty ${ }^{4}$. W sytuacjach, w których wydanie wyroku zależy wyłącznie od woli sędziego, zobligowany jest on w swoich decyzjach kierować się nie tylko własnym przekonaniem, ale musi działać w oparciu o zasady słuszności i mimo wszystko $\mathrm{w}$ granicach i zgodnie z prawem ${ }^{5}$. Władza bowiem w prawie legitymowana jest w dwojaki sposób: uprzednio i następczo ${ }^{6}$. Jej uprzedniość wyraża się przede wszystkim w tym, iż nie ma ona charakteru uzurpatorskiego, przyznaje się jej autorytet formalny ${ }^{7}$. Legitymacja następcza polega na tym, że sędzia wykonując swoje zadania działa zgodnie $\mathrm{z}$ prawem, biorąc pod uwagę przede wszystkim takie dobra jak sprawiedliwość i dążenie do dobra całej wspólnoty ${ }^{8}$.

Wyrok wydawany przez sędziego jest złożonym procesem myślowym, na który składają się przede wszystkim takie elementy jak podporządkowanie stanu faktycznego pod obowiązujące przepisy prawa, ewentualnie na wydaniu wyroku w granicach prawa - w ramach przysługujących sędziemu uprawnień dyskrecjonalnych. Mówi się o tym, że sąd kościelny spełnia funkcję pastoralną, kieruje się przede wszystkim „prymatem miłości”, a swobodna ocena dowodów jaka do sądów należy nie jest arbitralna ${ }^{9}$. Sędzia w wydawanym przez siebie wyroku osiągnąć musi pewność moralną, która opierać

\footnotetext{
${ }^{4}$ R. Sobański, Uwagi o tożsamości sędziego kościelnego, Prawo Kanoniczne 45 (2002) nr 3-4, s. 5.

${ }^{5}$ Od woli sędziego całkowicie uzależnione jest karanie za np. przestępstwo oszczerczego doniesienia kan. $1390 \$ 2$, lub fałszowanie dokumentów kościelnych kan. 1391.

${ }^{6}$ Tamże, s. 5.

${ }^{7}$ Tamże.

8 Tamże; KPK/1983 kan. $1446 \$ 1$ : „Wszyscy wierni, przede wszystkim zaś biskupi, winni pilnie pracować, by zachowując sprawiedliwość, na ile to możliwe, wykluczyć spory w Ludzie Bożym i jak najszybciej pokojowo je rozwiązywać”.

${ }^{9}$ R. Sobański, Uwagi o..., s. 6.
} 
się powinna na sile zebranych dowodów oraz wszystkich ustaleń w procesie ${ }^{10}$. Owa pewność moralna nie musi być absolutna, co dość myląco przedstawione zostało w przepisach kodeksowych. Pewność konieczna do wydania właściwego wyroku musi być kompromisem pomiędzy pewnością absolutną, a prawdopodobieństwem ${ }^{11}$. Ponadto sędzia musi zdawać sobie sprawę z tego, że normy prawne nie są celem samym w sobie, ale są jedynie środkiem do osiągnięcia właściwego rozwiązania.

Sędzia odznaczać się musi szczególnymi cechami osobowości, ponieważ prawodawca pod jego rozwagę kieruje wydanie wyroku, często pozostawiając mu autonomię w decydowaniu, aczkolwiek nie może on naruszać swoją arbitralnością norm rzeczowych rządzących procesem. To własna wiedza i sumienie sędziego określa czy zebrany materiał procesowy jest wystarczający, aby wydać wyrok. Pewność sędziego przy wymierzaniu sankcji karnej wymaga nie tylko działania rozumu ale i woli, gdyż wyrok nie może mieć cech spekulatywnych $^{12}$. To bardzo ważne, aby sędzia nie odwoływał się tylko i wyłącznie do tego, co zawarte jest w kodeksie, a więc jedynie do norm prawnych, albowiem wtedy to prawodawca stałby się sędzią,

\footnotetext{
${ }^{10}$ W. Szafrański, Pewność moralna w kościelnym wyroku sądowym, Prawo Kanoniczne 1(1958) nr 1-2, s. 28. Warto zauważyć, że nomenklatura pewności moralnej jest właściwa tylko i wyłącznie prawu kanonicznemu, w żadnym ustawodawstwie świeckim nie ma podobnego nazewnictwa, aczkolwiek można znaleźć pewne elementy tego pojęcia.

${ }^{11}$ Z. Grocholewski, Pewność moralna jako klucz do lektury norm procesowych, Ius Matrimoniale 3(1998), s. 21.

${ }^{12}$ KPK/1983 kan. 1608: „\$1. Do wydania jakiegokolwiek wyroku wymaga się u sędziego wewnętrznej moralnej pewności co do sprawy, która ma być rozstrzygnięta wyrokiem.

$\$ 2$. Tę pewność sędzia winien czerpać z faktów i dowodów.

$\S 3$. Dowody zaś sędzia powinien oceniać w swoim sumieniu, z zachowaniem przepisów ustawy o skuteczności niektórych dowodów.

$\$ 4$. Sędzia, który nie może osiągnąć takiej pewności, powinien orzec, że nie udowodniono uprawnienia powoda, a pozwanego uwolnionego odesłać, chyba że chodzi o sprawę cieszącą się przywilejem prawa, w którym to wypadku należy wydać wyrok na jej korzyść".
} 
gdyż ma on opierać się na całym materiale procesowyn, aby dążyć do prawdy obiektywnej ${ }^{13}$.

\section{Sędziowskie prawo laski}

Uprawnienie przyznane sędziemu określane jako sędziowskie prawa łaski związane jest $\mathrm{z}$ wymierzaniem kar ferendae sententiae, które to wychodzi naprzeciw przestępcy, działając na jego korzyść ${ }^{14}$. W ramach owego uprawnienia wymierzoną karę można złagodzić, odłożyć, zaniechać jej wymiar, a także warunkowo zawiesić wykonanie kary. Z owych uprawnień korzystać może także ordynariusz, który jako przełożony posiadający nie tylko władzę sądowniczą deklaruje bądź wymierza karę w postępowaniu pozasądowym ${ }^{15}$.

Uprawnienia sędziego określono w tym przypadku mianem prawa łaski, bowiem bez wątpienia działają one na korzyść sprawcy. W doktrynie jednak istniały spory, czy jest to właściwe określenie ze względu na nomenklaturę słowa „łaska”, bowiem najogólniej przyjmuje się, że łaska jest ofiarowaniem czegoś, co się komuś nie należy. Z drugiej jednak strony, jak podkreślają kanoniści, powyższe uprawnienie jest całkowicie fakultatywne, pozostawione swobodnemu uznaniu sędziego, dlatego słowo łaska jest jak najbardziej właściwe ${ }^{16}$. Ponadto owa łaska jest prawem, jakie sędziemu przysługuje, a owo prawo nie może być wykonywane poprzez kierowanie się tylko wolą, ale musi być zgodne z literą prawa.

Prawodawca nadaje sędziemu to wyjątkowe uprawnienie darząc go wyjątkowym zaufaniem, zezwalając mu na korzystanie z niego

\footnotetext{
${ }^{13}$ Z. Grocholewski, Pewność moralna..., s. 35.

${ }^{14}$ M. Mrrcha, Komentarz do Piątej Księgi Kodeksu Prawa Kanonicznego, t. II, Warszawa 1960, s. 411.

${ }^{15}$ J. Krukowski, Sankcje w Kościele, w: Komentarz do Kodeksu Prawa Kanonicznego z 1983 r., T. 4, Lublin 1987, s. 192; KPK/1983 kan. 1342 § 3: „Co ustawa lub nakaz mówią odnośnie do sędziego, gdy chodzi o wymierzanie lub deklarowanie kar w sądzie, należy stosować także do przełożonego, który dekretem pozasądowym wymierza lub deklaruje karę, jeśli nie wiadomo czego innego i nie chodzi a przepisy dotyczące jedynie procedury”.

${ }^{16}$ M. Mrrch A, Komentarz..., s. 411.
} 
według jego woli i uznania ${ }^{17}$. Jest to uprawnienie fakultatywne, które prawodawca wyraża słowami np. puniri potest ${ }^{18}$. Zazwyczaj możliwość niewymierzenia kary odnosi się do kary nieokreślonej (poena indeterminata), zaś jej złagodzenie do kary określonej (poena determinata ${ }^{19}$. Aczkolwiek jeśli kara jest określona, a karalność fakultatywna, sędzia może wymierzyć karę, jaka przewidziana jest w ustawie lub zaniechać jej wymiaru. W sytuacji, w której sędzia odstępuje od wymierzenia kary, musi to zostać odpowiednio uzasadnione, gdyż sędzia nie może działać całkowicie arbitralnie.

\section{Nadzwyczajne złagodzenie wymiaru kary}

Zasadniczo instytucja nadzwyczajnego złagodzenia kary polegać może na wymierzeniu kary przewidzianej za dane przestępstwo poniżej minimum zagrożenia ustawowego, bądź na zamianie kary surowszej na karę łagodniejszą ${ }^{20}$. Instytucję tą uważać należy za niezbędną, gdy ustawa wprost wskazuje minimum kary, relatywnie jeden rodzaj sankcji karnej. Co do ustaw, które wprowadzają minimum i maksimum wymiaru kary instytucja nadzwyczajnego złagodzenia kary nie jest potrzebna w stosunku do ustaw, które posiadają z góry określoną sankcję, ponieważ sędzia posiada swobodę w decydowaniu ${ }^{21}$. Aczkolwiek i takie sytuacje pozwalają sędziemu skorzystać z owego uprawnienia żeby „uchronić sędziego przed kolizją z własnym sumieniem"22.

${ }^{17}$ KPK/1983 kan. 1343: „Jeśli ustawa lub nakaz daje sędziemu władzę wymierzenia lub niewymierzenia kary, sędzia może także zgodnie ze swoim sumieniem i roztropnością złagodzić karę lub zamiast niej nałożyć pokutę".

${ }^{18}$ T. PAwluk, Prawo kanoniczne..., s. 103.

${ }^{19}$ M. Mrrcha, Komentarz..., s. 412.

${ }^{20}$ Tamże, s. 429; KPK/1983 kan. 1344, 2 : „Chociaż ustawa używa słów nakazujących, sędzia zgodnie z własnym sumieniem i roztropnością może:

$2^{\circ}$ powstrzymać się od wymierzenia kary lub wymierzyć karę mniejszą albo zastosować pokutę, jeśli winny się poprawił i naprawił zgorszenie albo jeśli został już przez władzę świecką wystarczająco ukarany lub przewiduje się, że będzie ukarany"; KPK/1917 kan. $2223 \$ 3,3^{\circ}$.

${ }^{21}$ Tamże, s. 430.

22 Tamże. 
Instytucja nadzwyczajnego złagodzenia kary wychodzi naprzeciw zasadzie indywidualizacji kary, co przejawia się tym, iż dostosowana jest do osoby przestępcy oraz znamion przedmiotowych popełnionego przez niego czynu ${ }^{23}$. Okazać się może, że w związku z różnymi względami jak np. wiek, stan zdrowia, wykształcenie, wysokość sankcji karnej jaką przewiduje konkretna ustawa może okazać się zbyt dotkliwa dla sprawcy. Jednocześnie prawodawca poprzez ustanowienie takiej instytucji, dzięki której złagodzić można ustawowe zagrożenie wyraża głębokie zaufanie do osoby sędziego, przede wszystkim do jego bezstronności oraz racjonalnego skorzystania z przyznanego mu uprawnienia.

Przywilej nadany sędziemu w postaci nadzwyczajnego złagodzenia kary jest uprawnieniem fakultatywnym, czyli sędzia może ukarać łagodniej jeśli okoliczności zachodzące $\mathrm{w}$ procesie stanowią przesłanki, które pozwolą mu podjąć taką decyzję. Niemniej sędzia może stwierdzić, iż mimo, że sprawca poprawił się, naprawił wyrządzoną przez siebie szkodę bądź został już ukarany przez władzę świecką należy wymierzyć dodatkowo karę łagodniejszą bądź nałożyć pokutę ${ }^{24}$.

Zasadniczo kara kościelna przede wszystkim prowadzić ma do poprawy przestępcy. Jest to jej zasadniczy cel, który jednak nie znosi poczytalności ani odpowiedzialności za popełnione przestępstwo. Prawodawca kościelny uprawnia jednak sędziego do złagodzenia ustawowego wymiaru kary przewidzianej za dane przestępstwo, ponieważ poprawa przestępcy i usunięcie zgorszenia ma fundamentalne znaczenie.

Nadzwyczajne złagodzenie kary może przejawiać się w dwóch formach, każda z nich uzależniona jest od słów jakie użyte zostały przez ustawodawcę w ustawie bądź nakazie karnym. Pierwsza forma obejmuje możliwość wymierzenia bądź odstąpienia od wymiaru kary, poprzez użycie słów fakultatywnych w ustawie, wtedy sędzia może złagodzić karę bądź wymierzyć w jej miejsce pokutę bądź zastosować

\footnotetext{
${ }^{23}$ J. Krukowski, Sankcje..., s. 192.

${ }^{24}$ J. SyryjCZy K, Sankcje..., s. 269.
} 
środek karny zaradczy ${ }^{25}$. Każde z tych uprawnień sędzia zobowiązany jest wykonywać zgodnie z sumieniem oraz roztropnością, aczkolwiek nie postępuje on całkowicie arbitralnie, gdyż musi dokładnie ustalić czy wszystkie względy i racje przemawiają za złagodzeniem odpowiedzialności karnej. Prawodawca stanowi, że sędzia powinien w szczególności skorzystać z tego uprawnienia, gdy zachodzą okoliczności zmniejszające poczytalność karną ${ }^{26}$.

Złagodzenie kary w tym przypadku przejawia się w tym, iż sędzia wymierzyć może karę o mniejszym stopniu dolegliwości niż kara pierwotnie przewidziana w ustawie bądź nakazie, np. zastosowanie interdyktu zamiast ekskomuniki bądź innych środków zaradczych zamiast kary ${ }^{27}$.

Drugą formą nadzwyczajnego złagodzenia kary jest sytuacja, gdy ustawodawca używa słów obligatoryjnych, które nakazują sędziemu skorzystanie z przyznanego mu uprawnienia wtedy sędzia zgodnie z sumieniem może złagodzić karę bądź wymierzyć pokutę, jeśli sprawca poprawił się bądź naprawił wyrządzoną przez siebie szkodę lub jeżeli kara wymierzona sprawcy przez władzę świecką jest wystarczająca ${ }^{28}$.

Przy podejmowaniu decyzji przez sędziego jaką karę wybrać, czy ją złagodzić czy zamienić na inny środek karny lub pokutę zobowiązany jest przede wszystkim brać pod uwagę wypracowaną oraz przyjętą praktykę kościelną, a także obowiązujące zasady i zwyczaj jeśli taki został wypracowany ${ }^{29}$.

Istnieć może sytuacja, gdy przestępstwo posiada naturę mieszaną, czyli podlega karalności władzy świeckiej i kościelnej. W przypadku przestępstwa mieszanego ukaranie przez władzę świecką nie uniemożliwia całkowicie wymierzenia kary przez władzę kościelną,

\footnotetext{
${ }^{25}$ J. KRUkowski, Sankcje..., s. 192. Fakultatywne słowa ustawy, które wymierzenie kary wskazują fakultatywnie (verba facultativa), np. iusta poena puniri potest.

${ }^{26} \mathrm{KPK} / 1983$ kan. $1324 \$ 1-2$.

${ }^{27}$ J. Krukowski, Sankcje..., s. 193.

${ }^{28}$ Nakazujące słowa ustawy (verba praeceptiva), to np. nakaz wyrażony w formie: iusta poena puniatur.

${ }^{29}$ J. Krukowski, Sankcje..., s. 193.
} 
bowiem kara zastosowana przez władzę świecką może nie być dostateczna ${ }^{30}$. W tej sytuacji prawodawca daje sędziemu możliwość do złagodzenia kary bądź wymierzenia pokuty stosownie do treści kan. 1344,2 KPK. Trzeba tutaj zauważyć, że kara świecka ma zupełnie inny wymiar niż kara kanoniczna. Kara wymierzana przez władzę świecką dotyka rzeczywistości doczesnej, materialnej, zaś kara kanoniczna dotyczy sfery duchowej, niematerialnej ${ }^{31}$. W takim wypadku każda z tych kar posiada odrębne właściwości, a przede wszystkim cele, dlatego nic nie stoi na przeszkodzie wymierzeniu kary w obu tych porządkach. Należy jednak pamiętać o proporcji, którą zachować trzeba podczas złożonego procesu jakim jest wymierzenie kary. To właśnie w momencie jej zachwiania sędzia skorzystać może $z$ uprawnienia do złagodzenia kary bądź zastąpienia jej pokutą ${ }^{32}$. Takie rozwiązanie prowadzi do osiągnięcia pełnej satysfakcji społeczeństwa w związku z właściwym wymiarem kary.

Oceniając instytucję nadzwyczajnego zaostrzenia kary przyznać należy, że bardzo wiele okoliczności przemawia na jej korzyść, w szczególności wymienić należy naprawę zgorszenia, poprawę sprawcy oraz naprawienie szkody wyrządzonej przez przestępcę. Ponadto instytucja ta w sposób indywidualny pozwala odnieść się do każdego przestępcy dostosowując karę do popełnionego przestępstwa oraz okoliczności, które temu popełnieniu towarzyszą.

\section{Odłożenie wymiaru kary}

W dawnym prawie kanonicznym nie ma wyraźnego zezwolenia na odłożenie wymiaru kary przez sędziego ${ }^{33}$. Poprzedni kodeks przewidywał taką sytuację i obok zasady ogólnej, według której sędzia

\footnotetext{
${ }^{30}$ J. Syry JCZY K, Sankcje..., s. 269.

${ }^{31}$ Tamże, s. 269.

${ }^{32}$ M. Mrrcha, Komentarz..., s. 434.

${ }^{33}$ Tamże, s. 413. Pewnych śladów tej instytucji można dopatrzeć się w dawnym prawie kanonicznym w szczególności w postępowaniu z Eutychesem gdzie Sąd po trzykrotnym wezwaniu Eutychesa, mógł wydać wyrok skazujący, jednakże przychylając się do jego prośby po trzecim wezwaniu, wymiar kary odłożono na późniejszy czas.
} 
musiał wymierzyć karę w każdej sytuacji, w której prawodawca używał słów nakazujących karalność przewidywał wyjątek, w którym sędzia mógł odłożyć wymiar kary na czas późniejszy ${ }^{34}$. Sędzia lub przełożony czynić mógł taki wyjątek zgodnie ze swoją roztropnością i uznaniem jeśli stwierdził, że ukaranie w tym czasie może spowodować powstanie większego zła.

System, który przewidziany był w poprzednim ustawodawstwie został powtórzony w Kodeksie Prawa Kanonicznego z 1983 r. w kan. $1344,1^{\circ}$ i wynika $\mathrm{z}$ niego, że może być stosowany tylko w nadzwyczajnych sytuacjach, aby uniknąć większego zła ${ }^{35}$. Kara staje się tym bardziej skuteczna, im szybciej następuje jej aplikacja. W zwyczajnym stanie rzeczy to właśnie zastosowanie kary powoduje usunięcie i zapobieżenie większego zła. Wyjątki obejmują sytuację, w której np. ukaranie sprawcy powoduje takie zgorszenie i emocje, że może to sprawić zerwanie jedności z Kościołem przez daną wspólnotę ${ }^{36}$. Co więcej, prawodawca nie wskazał określonych ram czasowych w których ma nastąpić wymiar kary więc sądzić należy, że zostało to powierzone ocenie sędziego, który może odłożyć karę na czas określony bądź nieokreślony ${ }^{37}$.

W związku z uprawnieniem sędziego do odłożenia kary powstaje pytanie czy to odłożenie dotyczy decyzji kończącej postępowanie, czyli decyzji lub dekretu, czy całego postępowania sądowego lub administracyjnego. Przede wszystkim prawodawca wskazał na odłożenie wydania dekretu lub wyroku, które wymierzają karę jednak w sytuacji, gdy możliwe jest powstanie większego zła należy odłożyć postępowanie procesowe lub administracyjne ${ }^{38}$. Sytuacja bowiem dużo bardziej niekorzystna wynikać może nie z wymierzenia

\footnotetext{
${ }^{34}$ M. Myrch A, Komentarz..., s. 414; KPK/1917 kan. $2223 \$ 3,1^{\circ}$.

${ }^{35} \mathrm{KPK} / 1983$ kan. 1344, 1: „Chociaż ustawa używa słów nakazujących, sędzia zgodnie z własnym sumieniem i roztropnością może:

$1^{\circ}$ odłożyć wymierzanie kary na czas bardziej odpowiedni, jeśli przewiduje się, że z większego ukarania winnego wypłynie większe zło;"

${ }^{36}$ J. Krukowski, Sankcje..., s. 193.

${ }^{37}$ J. SyryjCZy K, Sankcje..., s. 266.

${ }^{38}$ J. Krukowsкi, Sankcje..., s. 194.
} 
kary, ale z samego prowadzenia postępowania. Ponadto zupełnie bezzasadne wydaje się prowadzenie procesu jeśli kara ma nie zostać wymierzona $^{39}$.

Uprawnienie do odłożenia kary ma charakter fakultatywny i sędzia może skorzystać z niego według własnego uznania także wtedy, gdy ustawa używa słów nakazujących.

Prawodawca poprzez system odłożenia wymiaru kary przyjmuje, że jego podstawą jest przede wszystkim sprawiedliwość społeczna, co sprowadza się do zasad usprawiedliwiających prawo karania ${ }^{40}$. Przede wszystkim ustawodawca ma na względzie dobro ogólne do którego odnosi się ochrona społeczna.

Bez wątpienia to uprawnienie sędziego jest bardzo istotne i jak najbardziej uzasadnione, ponieważ daje gwarancję sprawiedliwego wymiaru kar, odpowiada na potrzeby społeczne oraz szanuje zasadę indywidualizacji kary.

\section{Zaniechanie wymiaru kary}

Instytucja ta znacznie różni się od odłożenia wymiaru kary na czas właściwszy nie tylko celem, ale przede wszystkim głębiej realizuje postulaty polityki kryminalnej ${ }^{41}$. Zauważyć również należy, iż zasadniczo odłożenie aplikacji kary jest przejawem rezygnacji władzy z odpłaty sprawiedliwej na rzecz odpłaty skutecznej, tak w sytuacji zaniechania wymiaru kary mamy do czynienia z rezygnacją z jakiejkolwiek odpłaty ${ }^{42}$. Rezygnacja $z$ kary za popełnione przestępstwo następuje gdy społeczeństwo, w tym przypadku dana wspólnota otrzymała równowartość kary w postaci poprawy przestępcy, a także naprawy zgorszenia ${ }^{43}$. Ponadto zasadnym wydaje się twierdzenie, że

\footnotetext{
${ }^{39}$ M. Myrcha, Komentarz..., s. 416.

${ }^{40}$ Tamże, s. 415. W prawie kanonicznym w odniesieniu do wymiaru kar uwzględnia się sprawiedliwość względną, czyli podyktowaną koniecznością ochrony społecznej. Gdyby bowiem podstawą karania była bezwzględna sprawiedliwość to nie byłoby mowy o istnieniu instytucji odłożenia kary.

${ }^{41}$ Tamże, s. 417.

${ }^{42}$ Tamże.

${ }^{43}$ J. Syry JCZy K, Sankcje..., s. 267.
} 
nie ma potrzeby wymiaru kary gdy spełnione są wymogi sprawiedliwości społecznej, a kara kanoniczna odniosła swój skutek ${ }^{44}$.

System zaniechania wymiaru kary był przewidziany w Kodeksie Prawa Kanonicznego z 1917 r. w następujących przypadkach: gdy sprawca został już ukarany lub przewiduje się, że zostanie ukarany w sposób wystarczający przez władzę świecką, jeżeli widoczna jest poprawa przestępcy i naprawił wyrządzone przez siebie zgorszenie ${ }^{45}$.

W obecnie obowiązującym kodeksie prawodawca przewiduje dwa przypadki, w których sędzia odstąpić może od wymierzenia kary, gdy karalność jest obligatoryjna: jeżeli nastąpiła całkowita poprawa przestępcy i sprawca naprawił powstałe zgorszenie, jeżeli sprawca dostatecznie ukarany został przez władzę świecką lub przewidzieć można, że będzie wystarczające ${ }^{46}$.

W pierwszym przypadku kiedy sędzia może odstąpić od wymierzenia kary poprawa sprawcy oraz naprawa zgorszenia wystąpić muszą kumulatywnie, jednocześnie, a sędzia korzysta ze swojego uprawnienia według własnego uznania ${ }^{47}$. Przy jednoczesnym zaistnieniu owych warunków prawodawca uważa, że porządek społeczny naruszony przez sprawcę został naprawiony ${ }^{48}$. Instytucja zaniechania wymiaru kary uwypukla cel jaki przede wszystkim spełniać ma kara kościelna, a chodzi tu oczywiście o poprawę sprawcy i naprawienie zła jakiego się dopuścił. Osiągnięcie tego celu sprawia, że uzasadnione jest powstrzymanie się od wymiaru kary oraz w pewien sposób daje to pewną satysfakcję wśród społeczeństwa ${ }^{49}$. Trzeba zauważyć, że naprawa wyrządzonego zgorszenia ma bardzo duże znaczenie ponieważ daje pełne odszkodowanie wspólnocie, i to jest maksimum jakie społeczność może osiągnąć od sprawcy.

\footnotetext{
${ }^{44}$ Tamże.

${ }^{45}$ J. Krukowski, Sankcje..., s. 194; KPK/1917 kan. $2223 \$ 3,2^{\circ}$.

${ }^{46}$ J. Syry JCZy K, Sankcje..., s. 267; KPK/1983 kan. 1344, 2.

${ }^{47}$ J. Krukowski, Sankcje..., s. 194.

${ }^{48}$ M. Mrrcha, Komentarz..., s. 420.

49 Tamże, s. 421.
} 
Skorzystanie przez sędziego z uprawnienia do zaniechania wymiaru kary jest $\mathrm{w}$ pewnym stopniu rezygnacją $\mathrm{z}$ wymiaru kary w ogóle. Niektórzy kanoniści określają to uprawnienie jako sędziowskie prawo darowania kary z powodu niewyraźnego, niedosłownego zwolnienia $\mathrm{z}$ niej ${ }^{50}$.

Z drugim przypadkiem kiedy sędzia może zaniechać wymiaru kary mamy do czynienia, gdy sprawca jest ukarany przez władzę świecką lub istnieje prawdopodobieństwo, że to nastąpi i to w sposób dostateczny. Jest to przypadek tzw. przestępstwa mieszanego mixti fori, kiedy obie władze zarówno kościelna jak i świecka kompetentne są do wymierzenia kary ${ }^{51}$. Wymierzenie kary przez władzę świecką nie pozbawia władzy kościelnej prawa karania, ale dla zachowania zasady sprawiedliwości prawodawca kościelny daje sędziemu możliwość do zaniechania wymierzania kary ${ }^{52}$. Ważne jest także to, że prawodawca starał się zachować proporcję między popełnionym przestępstwem, a wymierzoną karą i poprzez możliwość darowania kary uniknąć można podwójnej karalności jednego przestępstwa. Jest to bardzo istotne, ponieważ zasada podwójnej karalności - ne bis in idem pochodzi z prawa naturalnego i prawodawca wyraźnie nakazuje jej przestrzegania ${ }^{53}$.

Przyjąć należy, że w stosunku do przestępstw mieszanych prawodawca kościelny przyjął prymat karnych ustaw państwowych, ale nie wyłącza w tej materii kompetencji sądów kościelnych. Ustawodawca w kodeksie wyraźnie wskazuje bowiem, że sędzia zaniechać może wymiaru kary, gdy przestępca już został ukarany lub spodziewać się można ukarania w dostateczny sposób ${ }^{54}$.

Zaniechanie w sądownictwie kościelnym staje się obligatoryjne, gdy sędzia stwierdzi, że kara aplikowana przez władzę świecką jest

\footnotetext{
${ }^{50}$ Tamże.

${ }^{51}$ Tamże.

${ }^{52}$ J. Sy ry jCZy k, Sankcje..., s. 268.

${ }^{53}$ Tamże; M. Myrcha, Komentarz..., s. 423.

${ }^{54}$ J. Syry JCZy K, Sankcje..., s. 268.
} 
wystarczająca, a porządek społeczny został już przez nią przywrócony $^{55}$. Ukaranie przez sędziego spowodowałoby naruszenie wspomnianej już zasady sprawiedliwości oraz zasady ne bis in idem. Gdyby sędzia stwierdził, że kara świecka nie czyni zadość popełnionemu przestępstwu, może zastosować karę łagodniejszą od tej, która za dane przestępstwo przewidziana została przez ustawę bądź w jej miejsce wymierzyć pokutę ${ }^{56}$.

Zauważyć należy, że w przypadku zaniechania wymiaru kary należy także zrezygnować z prowadzenia postępowania, które zmierzałoby do wymierzenia kary, bowiem pozbawione byłoby ono swojego celu $^{57}$. Nadto gdyby okazało się, że w trakcie postępowania zaistnieją okoliczności upoważniające sędziego do rezygnacji z wymiaru kary, sędzia może zaniechać kontynuowania prowadzenia postępowania ${ }^{58}$. W Kodeksie Prawa Kanonicznego z 1917 r. zasadą było, iż przy darowaniu przez sędziego kary konieczny jest wyrok sądowy ${ }^{59}$. Ustalenie przez sędziego okoliczności, które przemawiały za zastosowaniem zaniechania kary powinno było zostać dokonane w wyroku. Co więcej sędzia zobowiązany był do wydania wyroku skazującego, który stwierdzał winę sprawcy z jednoczesnym wskazaniem, że sąd powstrzymał się od wymierzenia kary powołując się na wymienione w ustawie okoliczności ${ }^{60}$. Zaniechanie wymiaru kary, a co się także z tym wiąże zaniechanie przeprowadzenia procesu na gruncie poprzednich przepisów kodeksowych możliwe było w sytuacji, gdy kara była już wymierzona lub istniało prawdopodobieństwo, że zostanie wymierzona w sposób dostateczny przez władzę świecką. Było to zgodne z zasadą prawa naturalnego - ne bis in idem, a także w tym przypadku wiązało się z zachowaniem ekonomii procesowej gdyż

\footnotetext{
${ }^{55}$ M. Mrrcha, Komentarz..., s. 423.

${ }^{56}$ J. Krukowski, Sankcje..., s. 195.

${ }^{57}$ Tamże.

${ }^{58}$ Tamże.

${ }^{59}$ M. Myrcha, Komentarz..., s. 425; KPK/1917 kan. $2223 \S 3$ : „Si vero lex utatur verbis praeceptivis, ordinarie poena infligenda est”.

${ }^{60}$ M. Myrcha, Komentarz..., s. 425.
} 
zupełnie bezużytecznym staje się proces, gdy nie może prowadzić on do wymiaru kary ${ }^{61}$.

Prawodawca w obecnie obowiązującym kodeksie przewiduje sytuację nadzwyczajną, kiedy sędzia może powstrzymać się od wymierzenia kary ${ }^{62}$. Uprawnienie sędziego w tym przypadku odnosi się do okoliczności, które dotyczą sprawcy przestępstwa, zmniejszają jego poczytalność, a są to następujące przypadki: niepełne używanie rozumu przez sprawcę ${ }^{63}$, bojaźń lub wyższa konieczność będąca przyczyną przestępstwa ${ }^{64}$, wzburzenie umysłowe, które zaburza działanie władz umysłowych i wolitywnych ${ }^{65}$, nietrzeźwość bądź inne zakłócenie władz umysłowych pod wpływem których przestępstwo zostało dokonane ${ }^{66}$. Uprawnienie nadane sędziemu przez prawodawcę w kan. 1345 jest uprawnieniem fakultatywnym i skorzystać on może z niego po spełnionych wyżej wymienionych przesłankach ${ }^{67}$. Możliwość skorzystania przez sędziego z zaniechania wymiaru kary w takim przypadku uzależnione jest od uzyskania przez sędziego pewności, że w inny sposób faktycznie dojdzie do poprawy przestępcy.

Nigdy jednak nie może dojść do sytuacji, w której całkowicie nie zostanie nałożone na sprawcę zadośćuczynienie za popełniony czyn. W sytuacji, gdy przestępca zostaje uwolniony z kary sędzia może zastosować właściwe upomnienie, środki pasterskiej troski bądź inne środki zaradcze jeśli byłoby to wskazane dla dobra publicznego ${ }^{68}$.

${ }^{61}$ Tamże, s. 426.

${ }^{62}$ KPK/1983 kan. 1345: „Ilekroć przestępca miał jedynie niepełne używanie rozumu albo dopuścił się przestępstwa pod wpływem bojaźni, konieczności, wzburzenia uczuciowego lub w stanie nietrzeźwym bądź w innym podobnym wzburzeniu umysłu, sędzia może się także powstrzymać od wymierzenia jakiejkolwiek kary, jeśli uważa, że w inny sposób można lepiej osiągnąć jego poprawę".

${ }^{63} \mathrm{KPK} / 1983$ kan. $1324 \$ 1,1^{\circ}$.

${ }^{64} \mathrm{KPK} / 1983$ kan. $1324 \$ 1,5^{\circ}$.

${ }^{65} \mathrm{KPK} / 1983$ kan. $1324 \$ 1,3^{\circ}$.

${ }^{66} \mathrm{KPK} / 1983$ kan. $1324 \$ 1,2^{\circ}$.

${ }^{67}$ J. Syry JCZy K, Sankcje..., s. 273. Przepis kan. 1345 powinno się interpretować w świetle kan. $1324 \$ 1$.

${ }^{68}$ J. KRUKowsKi, Sankcje..., s. 195; KPK/1983 kan. 1348: „Gdy winny zostaje uwolniony od oskarżenia albo nie wymierza mu się żadnej kary, ordynariusz może 
Pamiętać bowiem należy, że rezygnacja $\mathrm{z}$ wymiaru kary nie znosi przestępstwa, winy, a także bezprawia czynu.

Zaniechanie wymiaru kary jest swoistym prawem, które przysługuje sędziemu po zmaterializowaniu się przesłanek, które zawarte są wyraźnie w kan. $1344,2^{\circ}$. Ustalenie czy owe przesłanki zostały spełnione, ocena stanu faktycznego prawodawca pozostawia sumiennemu i roztropnemu uznaniu sędziego, które oparte ma być przede wszystkim o przesłanki obiektywne, a nie subiektywne, które nie usprawiedliwiają takiego działania ${ }^{69}$. Sędzia działać musi zgodnie z zasadami sprawiedliwości oraz dokonywać reglamentacji sądów, aby dojść do prawdy obiektywnej.

\section{Warunkowe zawieszenie wykonania kary}

Instytucja warunkowego zawieszenia kary jest kolejną instytucją, która w pełni realizuje zasadę indywidualizacji kary ${ }^{70}$. Ponadto odnosi się do wychowawczego wymiaru postępowania karnego, w którym dochodzi do wydania wyroku skazującego, co tak naprawdę może okazać się wystarczającą odpłatą za popełnione przestępstwo, czyli spełnione zostają zadania prewencji szczególnej ${ }^{71}$. W przypadku tego systemu również jak przy zaniechaniu wymiaru kary następuje całkowita rezygnacja $z$ odpłaty za popełnione przestępstwo, ale pod warunkiem, że nastąpi poprawa przestępcy. Prawodawca poprzez wprowadzenie warunkowego zawieszenia wykonania kary wychodzi naprzeciw postulatom polityki kryminalnej i odnosi się do kary utylitarnie, przez co rezygnuje z przyjmowania koncepcji kary jako sprawiedliwej odpłaty za dokonane przestępstwo ${ }^{72}$.

Warunkowe zawieszenie wykonania kary polega na tym, że w wyroku skazującym stwierdzona zostaje wina sprawcy oraz orzeczona

odpowiednimi upomnieniami lub innymi środkami pasterskiej troski, albo nawet - gdy to jest wskazane - środkami karnymi zaradzić jego pożytkowi oraz dobru publicznemu".

${ }^{69}$ M. Myrcha, Komentarz..., s. 428.

${ }^{70}$ J. Krukowski, Sankcje..., s. 195.

${ }^{71}$ J. SyryjCzy , Sankcje..., s. 270.

${ }^{72}$ Tamże. 
jest kara, z jednoczesnym jej zawieszeniem na okres próby, której sprawca jest poddany ${ }^{73}$. System taki wprowadzony został, aby zaradzić w jakiś logiczny sposób demoralizacji przypadkowych przestępców, odcierpieniem kary, w szczególności pobytem w więzieniu, które mimo wszystko zawsze pozostanie szkołą przestępstwa ${ }^{74}$. Instytucja warunkowego zawieszenia kary jest stosunkowo młoda, bowiem w prawie kanonicznym wprowadził ją dopiero Kodeks Prawa Kanonicznego z 1917, wcześniej ciężko dopatrzeć się jej śladów ${ }^{75}$. Obecnie stosowana jest ona powszechnie, aczkolwiek rozumiana jest w różnoraki sposób. Prawodawca w poprzednim, a także w obecnie obowiązującym kodeksie przyjął system belgijsko - francuski, według którego sąd w wyroku orzeka o winie i karze, natomiast wykonanie wyroku wstrzymuje warunkowo na pewien czas, który jest okresem próby $^{76}$.

Ustawodawca w Kodeksie Prawa Kanonicznego z 1983 r. znacznie złagodził warunki zastosowania warunkowego zwieszenia kary w stosunku do poprzedniego kodeksu. I tak sędzia skorzystać może z przysługującego mu uprawnienia gdy: sprawca po raz pierwszy dopuścił się przestępstwa, nie ma potrzeby naprawienia zgorszenia, za popełnione przestępstwo w ustawie lub nakazie karnym przewidziana

\footnotetext{
${ }^{73}$ Tamże; KPK/1983 kan. 1344, 3요 „Jeśli winny dopuścił się przestępstwa po raz pierwszy po latach nienagannie przeżytych, a nie zachodzi konieczność naprawienia zgorszenia, zawiesić obowiązek przestrzegania kary ekspiacyjnej, tak jednak, że gdyby winny w okresie oznaczonym przez sędziego ponownie dopuścił się przestępstwa, poniesie karę za obydwa przestępstwa, chyba że już upłynął czas przedawnienia skargi karnej z racji pierwszego przestępstwa”.

${ }^{74}$ M. Myrcha, Komentarz..., s. 442; J. Krukowski, Sankcje..., s. 195.

${ }^{75}$ KPK/1917 kan. 2288.

${ }^{76}$ M. Myrcha, Komentarz..., s. 443; J. Krukowski, Sankcje..., s. 196. Prócz systemu belgijsko - francuskiego, który został przyjęty w obydwu Kodeksach Prawa Kanonicznego doktryna wyróżnia także system anglo - amerykański, który polega na tym, że sąd nie wydaje wyroku skazującego lub wydaje wyrok jedynie stwierdzający winę ale nie orzeka kary, oraz system niemiecki wg którego następuje ułaskawienie przestępcy przez organ władzy administracyjnej lub przez głowę państwa po uprzednim wydaniu wyroku stwierdzającego winę i karę.
} 
jest kara ekspiacyjna ${ }^{77}$. Niemożliwe jest zastosowanie warunkowego zawieszenia kary w stosunku do recydywistów, czyli przestępców którzy poprzednio byli już karani. Nie chodzi tutaj o wcześniejsze popełnienie jakiegokolwiek przestępstwa, ale ważne jest aby sprawca w ogóle nie był karany ${ }^{78}$. Nie dopuszczalna jest również sytuacja, w której doszło do zaniechania wymiaru kary.

Drugim bardzo ważnym warunkiem jest brak potrzeby naprawienia zgorszenia spowodowanego przestępstwem, bowiem nie uwzględnienie go mogłoby doprowadzić do jeszcze większego zgorszenia i spowodowałoby wielką szkodę dla Kościoła i jego wiernych ${ }^{79}$.

Warto zauważyć, że ustawodawstwo świeckie zawiera dodatkowo uregulowania dotyczące wynagradzania szkody, co nie znajduje się w Kodeksie prawa kanonicznego. W doktrynie jednak istnieje pogląd, że warunek ten jest uwzględniany, ponieważ naprawienie szkody jest pojęciem zdecydowanie węższym niż naprawienie zgorszenia i zawiera się w nim ${ }^{80}$.

Prawodawca w odniesieniu do kary stawia wymóg stosowania instytucji warunkowego zawieszenia kary tylko do kar ekspiacyjnych tym samym wykluczając możliwość jej zastosowania do kar popraw$\mathrm{czych}^{81}$. Może być to natomiast kara wskazana zarówno w ustawie, nakazie karnym jak i wymierzona w wyroku sądowym bądź dekrecie administracyjnym.

\footnotetext{
${ }^{77}$ J. Syry JCZy K, Sankcje..., s. 271.

${ }^{78}$ Tamże.

${ }^{79}$ M. Mrrcha, Komentarz..., s. 450.

${ }^{80}$ Tamże.

${ }^{81}$ J. SyRY JCZYK, Sankcje..., s. 271. W KPK/1983 nazwa kary ekspiacyjne zastąpiła pojęcie kary odwetowej, która istniała w KPK/1917, a to ze względu na wydźwięk, ponieważ obecny kodeks przede wszystkim stawia za cel poprawę przestępcy a nie odwet. Nawet jeśli odwet jest w jakimś stopniu celem to nie jest on bezpośredni i traci w tym znaczeniu negatywny wydźwięk. Zasadniczym celem kar ekspiacyjnych jest zadośćuczynienie wspólnocie wiernych za popełnione zło, czyli zmierzają one do naprawienia naruszonego porządku.; KPK/1917 w kan. 2288 wykluczał możliwość zastosowania warunkowego zawieszenia wykonania kar najcięższych na duchownych np. depozycji, degradacji, pozbawiania urzędu lub beneficjum. W obecnym kodeksie nie ma takiego ograniczenia.
} 
Warto teraz odnieść się do samej istoty instytucji warunkowego zawieszenia kary, którą jest przede wszystkim poddanie sprawcy próbie. Okres próby wyznacza sędzia, aczkolwiek prawodawca oczekuje, aby czas ten dostosowany był do konkretnej sytuacji np. gdy popełnione przestępstwo jest małej wagi, a chęć poprawy sprawcy nie budzi wątpliwości ${ }^{82}$. Co więcej, wspomniany okres próby nie może być dłuższy od czasu przedawnienia skargi karnej za pierwsze przestępstwo, czyli skargi o wykonanie kary ${ }^{83}$. W Kodeksie Prawa Kanonicznego z 1917 roku okres zawieszenia kary wynosił trzy lata.

Obecnie prawodawca nie przewiduje nadzoru nad sprawcą będącym w okresie próby, a także nie nakłada na niego żadnych dodatkowych obowiązków jakie stosuje prawodawca świecki ${ }^{84}$. Jedynym warunkiem jaki postawiony jest sprawcy, to aby w okresie próby określonym przez sędziego nie popełnił on kolejnego przestępstwa ${ }^{85}$. Jeżeli przestępca we wskazanym czasie nie dopuści się przestępstwa karę uważa się za niebyłą. W sytuacji, w której sprawca nie dotrzymuje tego warunku kara zostaje odwieszona i następuje jej wymierzenie zarówno za pierwsze jak i za drugie popełnione przez niego

82 T. PAWLuk, Prawo kanoniczne..., s. 104.

${ }^{83}$ J. Syry JCZY K, Sankcje..., s. 271; KPK/1983 kan. 1362: „\$1. Skarga karna wygasa na skutek przedawnienia po upływie trzech lat, chyba że chodzi:

$1^{\circ}$ o przestępstwa zarezerwowane Kongregacji Nauki Wiary;

$2^{\circ}$ o skargę z tytułu przestępstw, o których w kan. 1394, 1395, 1397, 1398, która przedawnia się po upływie pięciolecia;

$3^{\circ}$ o przestępstwa, które nie są karane prawem powszechnym, jeśli prawo partykularne ustanowiło inny termin przedawnienia.

$\$ 2$. Przedawnienie liczy się od dnia popełnienia przestępstwa, lub, jeśli przestępstwo jest permanentne bądź habitualne, od dnia jego ustania;

KPK/1983 kan. 1363: „\$1. Jeśli w terminach podanych w kan. 1362, od dnia, w którym wyrok skazujący przeszedł w stan rzeczy osądzonej, oskarżony nie został powiadomiony o dekrecie wykonawczym sędziego, o czym w kan. 1651, przedawnieniu ulega skarga o wykonanie kary.

$\$ 2$. To samo obowiązuje odpowiednio, jeśli kara została wymierzona przez dekret pozasądowy.

${ }^{84}$ W. Wróbel, A. Zoll, Polskie prawo karne. Część ogólna, Kraków 2010, s. 487.

${ }^{85}$ J. Syry JCZy K, Sankcje..., s. 271. 
przestępstwo, chyba, że skarga karna za pierwsze przestępstwo uległa już przedawnieniu ${ }^{86}$. W takim przypadku następuje zbieg kar za obydwa przestępstwa co sprawia, że sankcja jest bardziej dotkliwa i odczuwalna, ale jest to jak najbardziej uzasadnione celem instytucji zawieszenia kary.

Warto zauważyć, że w stosunku do ustawodawstwa świeckiego można dojść do wniosku, iż prawo kanoniczne jest bardziej surowe, ponieważ nakazuje wykonanie zawieszonej kary w momencie popełnienia jakiegokolwiek przestępstwa podczas, gdy polski kodeks karny wiąże to $\mathrm{z}$ popełnieniem przestępstwa podobnego i umyślnego ${ }^{87}$. Ponadto $\mathrm{w}$ prawie kanonicznym obowiązek cofnięcia zawieszenia kary jest bezwarunkowo obligatoryjny podczas, gdy prawodawca świecki określa to uprawnienie jako fakultatywne ${ }^{88}$.

Instytucja warunkowego zawieszenia kary oparta jest przede wszystkim na założeniu, że osoba popełniająca przestępstwo po raz pierwszy może nie mieć do końca świadomości zła jakiego się dopuszcza i jakie skutki może to zło wywołać ${ }^{89}$. Uprawnienie to nadane sędziemu stworzone jest celem przyznania szansy popełniającemu przestępstwo opamiętania się oraz zerwania z przestępczością o „własnych siłach i w warunkach korzystnych dla niego" ${ }^{90}$. Warunkowe zawieszenie kary określane jest jako specjalny sposób uwolnienia od kary, zanim sprawca rozpocznie jej realizowanie i odnosi się do dobra sprawcy przestępstwa.

\footnotetext{
${ }^{86}$ T. Pawluk, Prawo kanoniczne..., s. 104; J. Krukowski, Sankcje..., s. 196.

${ }^{87}$ M. Mrrcha, Komentarz..., s. 453.

${ }^{88}$ W. Wróbel, A. Zoll, Polskie prawo..., s. 488; kk/1997 art. 69 \$1: „Sąd może warunkowo zawiesić wykonanie orzeczonej kary pozbawienia wolności nie przekraczającej 2 lat, kary ograniczenia wolności lub grzywny orzeczonej jako kara samoistna, jeżeli jest to wystarczające dla osiągnięcia wobec sprawcy celów kary, a w szczególności zapobieżenia powrotowi do przestępstwa”.

${ }^{89}$ T. PAWluk, Prawo kanoniczne..., s. 104.

90 Tamże.
} 


\section{Nadzwyczajne podwyższenie kary}

System nadzwyczajnego zaostrzenia kary wychodzi naprzeciw zasadzie indywidualizacji kary oraz jest swoistym, dość specyficznym uprawnieniem nadanym sędziemu. Występuje zazwyczaj, kiedy sankcja karna przewidziana w ustawie lub nakazie karnym jest niewystarczająca, wtedy sędzia wyjść może poza maksimum ustawowe przewidziane za dane przestępstwo. Owe uprawnienie polegać może także na połączeniu z karą główną innego środka karnego i w takiej formie znajduje zastosowanie najczęściej. Co więcej, należy stwierdzić, że uprawnienie do zaostrzenia odpowiedzialności ma na celu podkreślenie wagi popełnionego przestępstwa ${ }^{91}$.

W dawnym ustawodawstwie kościelnym nie istniała możliwość zaostrzenia kary, ponieważ sędzia sądzić miał według ustaw, a nie o ustawach ${ }^{92}$. Jako pierwszy lukę wypełnił Kodeks Prawa Kanonicznego z 1917 r., w którym zawarta była zasada, iż sędzia nie mógł zaostrzyć kary oznaczonej chyba, że w sytuacji wystąpienia nadzwyczajnych okoliczności ${ }^{93}$. Obecnie prawodawca kodeksowy wychodzi naprzeciw sytuacjom, w których zachodzą warunki nie przewidziane przez niego, a kara określona jest niewystarczająca ${ }^{94}$. Okoliczności prowadzące do zaostrzenia kary zawarte w kan. $1326 \$ 1,1^{\circ}-3^{\circ}$ a więc: recydywa, nadużycie władzy lub urzędu do popełnienia przestępstwa, działanie sprawcy z winą umyślną zbliżoną do umyślności są jedynymi możliwościami zastosowania tego uprawnienia i nie mają na niego wpływu żadne okoliczności pozaustawowe, choćby świadczyły o zwiększeniu poczytalności karnej sprawcy ${ }^{95}$. Warto zauważyć, że owe okoliczności podnoszą poczytalność prawno - karną. Uprawnienie do podwyższenia kary jest uprawnieniem nadzwyczajnym.

W kanonistyce często dyskutowano jak należy rozumieć okoliczności, które prowadzą do wyjścia poza maksimum ustawowe

\footnotetext{
${ }^{91}$ A. G. Urru, Punire per salvare. Il sistema penale nella Chiesa, Roma 2001, s. 69.

92 J. Krukowski, Sankcje..., s. 197.

93 Tamże.; KPK/1983 kan. 1326.

${ }^{94}$ M. Mүrсна, Komentarz..., s. 395.

95 J. Syry JCZy K, Sankcje..., s. 178.
} 
przewidziane w sankcji karnej, bowiem prawo kanoniczne nie posługuje się ustawową gradacją kar, jaka ma miejsce w prawie świeckim.

W Kodeksie Prawa Kanonicznego z 1983 r. prawodawca zawarł zasadę, że nie powinno się wymierzać kar cięższych, a przede wszystkim cenzur, gdy kara pozostaje nieokreślona ${ }^{96}$. Kara powinna być określona co do rodzaju i wysokości i wtedy poddawana być może zaostrzeniu. Warto zauważyć, że w części szczegółowej prawa karnego ustawodawca często nie określa sankcji karnej, ale wówczas nakazuje sędziemu działać według własnego, roztropnego uznania ${ }^{97}$. Co więcej sędzia kierować się powinien regułami zawartymi w kan. 1349, które są przejawem łagodności w sposobie aplikowania kar w Kościele ${ }^{98}$. W związku z tym, iż instytucja nadzwyczajnego zaostrzenia kary jest uprawnieniem nadzwyczajnym, specyficzna jest forma w jakiej do niego dochodzi, bowiem uzależnione jest to od tego czy zaostrzeniu ma być poddana kara latae sententiae czy ferendae sententiae.

W odniesieniu do przestępstwa, które zagrożone jest karą ferendae sententiae sędzia lub przełożony może wymierzyć surowszą karę, niż ta która jest przewidziana za to przestępstwo. Ponieważ Kodeks nie określa konkretnego sposobu w jaki ma dojść do zaostrzenia odpowiedzialności należy uważać, iż poddane to zostało swobodnej ocenie sędziego. Jednak nie jest to zadanie łatwe, gdyż prawo kanoniczne nie posługuje się „ustawową gradacją poszczególnych środków karnych"99. Dlatego należy odnosić się indywidualnie do każdej zaostrzanej kary i w stosunku do niej określać wyjście poza maksimum ustawowe. Przyjmuje się, że zwiększenie kary ekspiacyjnej może polegać na przedłużeniu czasu trwania tej kary, na podniesieniu jej górnej granicy, np. w przypadku grzywny na jej podwyższeniu, zaś

\footnotetext{
${ }^{96}$ J. Krukowski, Sankcje..., s. 197.

${ }^{97}$ J. Syry JCZy K, Sankcje..., s. 180.

${ }^{98}$ KPK/1983 kan. 1349: „Jeśli kara jest nie określona, a ustawa czego innego nie zastrzega, sędzia nie powinien wymierzać cięższych kar, zwłaszcza cenzur, chyba że domaga się tego bezwzględnie ciężkość przypadku; kar zaś wiążących na stałe nie może wymierzać".

99 J. Syry JCZYK, Sankcje..., s. 179.
} 
w stosunku do kar poprawczych mówi się o zaostrzeniu warunków zwalniania $\mathrm{z}$ nich ${ }^{100}$.

Istnieje spór w doktrynie odnoszący się do mechanizmu jakim kara ma być zaostrzona. Dominującym jest pogląd, iż owe zaostrzenie odpowiedzialności polega nie na zamianie wymierzonej kary na karę ostrzejszą lecz na dołączeniu do kary głównej np. pokuty kanonicznej ${ }^{101}$. Większość kanonistów opowiada się za stanowiskiem, iż w samym zwrocie ustawowym "gravius punire” jest mowa o zaostrzeniu kary głównej. Ponadto w przypadku kar latae sententiae nie ma mowy o zamianie kary, dlatego forma zaostrzenia kary wiążącej mocą samego prawa jest inna niż w przypadku kary ferendae sententiae. Jest to jak najbardziej trafne i logiczne unormowanie przyjęte przez prawodawcę ponieważ kara latae sententiae jest karą najcięższą, ponadto nakładana jest na sprawcę w momencie popełnienia przestępstwa, dlatego nie ma też mowy o jakiejkolwiek zamianie na inną karę.

Prawodawca w $\$ 2$ kan. 1326 uprawnia sędziego w przypadku, gdy za przestępstwo została przewidziana kara latae sententiae, sędzia w momencie deklaracji kary może orzec również o dołączeniu dodatkowo innej kary bądź pokuty ${ }^{102}$. W odniesieniu do formy zaostrzenia kary w przypadku kar ferendae sententiae możemy mówić o zaostrzeniu kary w trzech postaciach ${ }^{103}$ : w postaci wyjścia poza ustawowe maksimum kary, dołączenia do kary głównej innego środka karnego stanowiącego karę dodatkową oraz w postaci dołączenia do kary podstawowej kary pokutniczej ${ }^{104}$.

\footnotetext{
${ }^{100}$ M. Myrcha, Komentarz..., s. 404.

${ }^{101}$ Odmienny pogląd prezentuje A. MarzoA w: Comentario al. C. 1326, en: Com. Ex. CDC, vol. IV/1, s. 328.

${ }^{102}$ J. Syry JCZy K, Sankcje..., s. 180; KPK/1983 kan. $1326 \$ 2$ : „Jeśli w wypadkach, o których w $\$ 1$, przewidziana jest kara wiążąca mocą samego prawa, można do niej dołączyć inną karę lub pokutę".

103 Tamże, s. 179.

${ }^{104}$ M. Myrcha, Komentarz..., s. 403. Warto zauważyć, że M. Myrcha w Komentarzu do księgi IV KPK z 1917 r. wymienia tylko dwie pierwsze postaci, nic nie wspominając o pokucie kanonicznej.
} 
Reasumując powyższe stwierdzić należy, że instytucja nadzwyczajnego zaostrzenia kary wprowadzona została głównie w celu zindywidualizowania kary, która właściwa jest konkretnemu przestępcy dopuszczającemu się czynu zabronionego. Wychodzi ona także naprzeciw potrzebom wspólnoty, która może czuć się w pełni bezpieczna, ponieważ prawodawca kościelny poprzez zaostrzenie kary wzbudza respekt oraz działa prewencyjnie na potencjalnych przestępców.

\section{Sposób wymiaru kar przy zbiegu przestępstw}

W literaturze prawa kanonicznego wymiar sankcji karnej przy zbiegu przestępstw nie jest metodologicznie połączone z nomenklaturą dyskrecjonalnych uprawnień sędziego. Prawodawca w kan. 1346 wyraźnie jednak wskazuje na swobodę i roztropność sędziego w przypadku wymierzania kary przy zaistnieniu zbiegu przestępstw ${ }^{105}$. Tym samym jest to swoiste uprawnienie sędziego, który korzystając ze swoich kompetencji i swobodnego uznania związanego z literą prawa podejmuje decyzję o złagodzeniu kar w słusznych granicach.

Zagadnienie wymiaru kar w przypadku zbiegu przestępstw, którego dopuścił się ten sam przestępca przysparza wielu trudności z powodu istnienia trzech systemów wymiaru kar w tym przypadku ${ }^{106}$. Prawodawca w Kodeksie Prawa Kanonicznego z 1983 r. wychodzi naprzeciw zasadzie materialnej kumulacji kar, która powtórzona

\footnotetext{
${ }^{105}$ KPK/1983 kan. 1346: „Ilekroć winny popełnił wiele przestępstw i zbyt wielka byłaby suma kar, które należałoby mu wymierzyć, pozostawia się roztropnemu uznaniu sędziego złagodzenie kar w słusznych granicach”; KPK/1917 kan. $2224 \$ 1$. ${ }^{106}$ J. KRUKowski, Sankcje..., s. 200. Istnieją trzy zasadnicze systemy wymiaru kar w sytuacji zbiegu przestępstw: system materialnej kumulacji kar polegający na wymierzeniu tylu kar ile popełniono przestępstw, a następnie dokonuje się ich zsumowania. System absorpcji, w którym następuje wymierzenie kary za najcięższe przestępstwo natomiast kary mniejsze uważa się za pochłonięte przez karę największą oraz system kumulacji prawnej zwany aspiracyjnym, przejawia się w dwóch formach: albo następuje podwyższenie maksimum ustawowego najwyższej kary bądź najpierw następuje wymiar kar za poszczególne przestępstwa, a następnie w ich miejsce stosuje się osobną karę tzw. karę łączną.
} 
została za poprzednim kodeksem. Polega ona na wymierzeniu tylu kar, ilu przestępstw dopuścił się sprawca - Ordinarie tot poenae quot $\operatorname{delicta}^{107}$. Jest to system zdecydowanie najprostszy, ponieważ dochodzi do mechanicznego połączenia wszystkich kar zdeklarowanych za każde przestępstwo ${ }^{108}$. Należy zauważyć, iż pomimo że system ten w pełni oddaje istotę sprawiedliwości, to jednak spotyka się z wieloma głosami krytycznymi. W niektórych sytuacjach bowiem, jest on po prostu niemożliwy do zastosowania i w takich sytuacjach posługiwać się należy systemem absorpcji. Potrzeba taka zachodzi w sytuacji, gdy suma kar ferendae sententiae jest zbyt duża, aby je aplikować dlatego rozważnemu uznaniu sędziego poddaje się decyzję o możliwości złagodzenia kary w słusznych granicach ${ }^{109}$. Jest to wyjątek od zasady i dopuszczalny jest tylko przy wymiarze kar ferendae sententiae, bowiem w odniesieniu do kar latae sententiae zawsze zachodzi kumulacja materialna ${ }^{110}$. Jest to rozwiązanie jak najbardziej poprawne, ponieważ suma kar ferendae sententiae może okazać się zbyt dotkliwa dla sprawcy, wtedy system materialnej kumulacji okazuje się zbyt surowy. W przypadku kar latae sententiae sprawca zaciąga je automatycznie $\mathrm{w}$ momencie popełnienia czynu przestępnego, bez jakiejkolwiek interwencji sędziego czy przełożonego, którzy karę tą mogą jedynie zadeklarować111.

Sędzia może złagodzić sumę kar, albo zaostrzając karę najbardziej surową z wymierzonych i dodać do niej pokutę lub którąś z kar lżejszych, bądź redukując sumę kar w zasadnych granicach poprzez zastosowanie kary łącznej ${ }^{112}$. Prawodawca w kan. 1346 upoważnia sędziego do zastosowania systemu kumulacji prawnej w formie kary łącznej, która zastępuje odrębne kary za poszczególne przestępstwa.

\footnotetext{
107 T. PAwluk, Prawo kanoniczne..., s. 105.

${ }^{108}$ M. Myrcha, Komentarz..., s. 493.

${ }^{109}$ J. Syry JCZy k, Sankcje..., s. 275; J. Krukowski, Sankcje..., s. 201.

${ }^{110}$ T. Pawluk, Prawo kanoniczne..., s. 105; J. Syry jCzy к, Sankcje..., s. 275.

${ }^{111}$ J. SyryjCzyk, Sankcje..., s. 275.

112 J. Krukowski, Sankcje..., s. 201; J. SyryjCzyk, Sankcje..., s. 275.
} 
Warto zauważyć w jaki sposób prawodawca ujął możliwość wymierzenia przez sędziego kary łącznej. Nie podaje on żadnych reguł jakimi sędzia powinien się posłużyć, nadmienia jedynie, iż powinien uczynić to zgodnie ze swoim roztropnym uznaniem ${ }^{113}$. Swoboda przyznana sędziemu pokazuje zaufanie jakim darzy go prawodawca oraz wskazuje na uwypuklenie zasady indywidualizacji kary w razie zbiegu przestępstw ${ }^{114}$. Stwierdzić należy, że w tym przypadku sędzia skorzystać może z przyznanego mu sędziowskiego prawa łaski. Stanowisko prawodawcy kościelnego pokazuje, że w Kościele o wiele łatwiej wymierzyć karę łączną, ponieważ skutki kar nakładają się na siebie ${ }^{115}$.

Ustawodawca $\mathrm{w}$ unormowaniu dotyczącym zbiegu przestępstw odnosi się do sprawiedliwości przy wymiarze kar podkreślając, że wymiar ten nie opiera się na sprawiedliwości bezwzględnej, ale na sprawiedliwości w ramach dobra ogólnego w tym samego przestępcy ${ }^{116}$.

\section{Zakończenie}

Reasumując, należy zauważyć, że prawodawca kodeksowy nadając szereg uprawnień sędziemu wskazuje na niezwykle wysoki stopień zaufania w stosunku do jego osoby i podejmowanych przez niego działań. Sędzia czy przełożony są podmiotami uprzywilejowanymi co sprawia, że posiadają oni dużą swobodę w podejmowaniu decyzji, ale pamiętać należy, że każdy z nich działać musi w granicach i zgodnie $\mathrm{z}$ literą prawa. Żaden bowiem $\mathrm{z}$ podmiotów władzy nie jest $\mathrm{w}$ swoich działaniach całkowicie arbitralny, ponieważ stoją oni na straży wartości, które są niezwykle istotne dla całego Kościoła i składającej się na niego wspólnoty.

Możliwości jakimi posłużyć się może sędzia czy to zwolnienie z kary, złagodzenie jej wymiaru, a nawet jej zaostrzenie pokazują, że Kościół wychodzi naprzeciw potrzebom wspólnoty. Co więcej, sędzia dostosowuje wymiar kary do całości zebranego materiału w toku

\footnotetext{
113 T. PAwluk, Prawo kanoniczne..., s. 105; J. Krukowski, Sankcje..., s. 201.

${ }^{114}$ J. Krukowski, Sankcje..., s. 201; J. Sy RYjCZy K, Sankcje..., s. 275.

${ }^{115}$ J. KRUKOWsKi, Sankcje..., s. 201.

${ }^{116}$ J. Syry JCZy K, Sankcje..., s. 275.
} 
postępowania, co pozwala na zachowanie zasady sprawiedliwości względnej.

Uprawnienia dyskrecjonalne oraz procedura ich wdrażania w konkretnym przypadku wskazuje na to, jak nieskazitelnym charakterem musi odznaczać się sędzia skoro w wielu przypadkach wymiar kary zależy od jego roztropnego uznania.

\section{Optional permissions of the judge in the judicial procedure ecclesiastical penalties}

The issue of discretionary power of the judge is closely connected with the theory of law and using it in practice, although this relationship is not entirely clear. The law theory focuses on legal standards, on the context in which the law does and should affected, it refers to the broad rules, because the rule of law makes a particular pattern of behavior. On the other hand, we have to deal with the statements in these rule of law, which indicate one the possibility of a judge in making a specific activity, in particular the use of available legal norm.

The legislature in the Code of Canon Law of 1983. In some cases, gives expression to the discretionary power of the judge. It must be held that this power is a sphere of activity in which the authority may act according to their beliefs settle within the so-called. discretion.

In most cases, the freedom in imposing penalties is governed by legislation, although the legislature also gives the judge the power margin and leaves him complete freedom when fixing, tightening and not to impose criminal sanctions. In each of these cases, the judge must behave in accordance with their conscience and prudence, taking into account the principle of fairness, but also to national circumstances. The legislator dipped by giving so much autonomy in action a person judge shows its important role and places it very high in the hierarchy of government entities.

Judgment of the judge is a complex thought processes. It consists of a subordination of the facts under the applicable law, eventually judgment within the law in the exercise of the judge's discretion.

In the hereby article it will be presented the institutions that confer the judge the power to use his discretionary power, such as extraordinary mitigation and enhancement of the penalty, judicial pardon, conditional 
suspension of execution of sentence, failure to sentencing and postpone sentencing.

SŁOWA KLUCZowe: dyskrecjonalna władza sędziego, nadzwyczajne złagodzenie i obostrzenie kary, sędziowskie prawo łaski, warunkowe zawieszenie wykonania kary, zaniechanie wymiaru kary oraz odłożenie wymiaru kary.

KEY WORDS: discretionary power of the Judge, extraordinary mitigation and enhancement of the penalty, judicial pardon, conditional suspension of execution of sentence, failure to sentencing, postpone sentencing.

Nota o Autorze:

MGR LIC. Sylwia MARCZYK - doktorantka studiów doktoranckich na Wydziale Prawa Kanonicznego Uniwersytetu Kardynała Stefana Wyszyńskiego w Warszawie. 